\title{
POLITITIKK

\section{Tidsskriftet Internasjonal Politikk 80 år! Fornyet fokus på Skandinavia, Norden og tverrfaglighet}

2017 markerer et dobbelt jubileum for tidsskriftet Internasjonal Politikk (IP): 80åringen utkommer i sin 75. årgang! Fra sin spede begynnelse som «småskrifter om aktuelle utenrikspolitiske spørsmål» har IP i dag blitt et av International Relations' eldste fagtidsskrifter. IP er i dag også et av Nordens mest tradisjonsrike fagtidsskrifter. Innen fagområdet Internasjonal Politikk er IP sågar det ledende tidsskriftet i Norden. Vi innleder derfor feiringen med en storslagen Fokusspalte om USA og Skandinavia. Dette gjenspeiler ikke bare vår ambisjon om å gjøre IP mer relevant for miljøer utenfor Norges grenser, men spiller også på det første «småskriftet» som ble gitt ut i mai 1937 og som dannet grunnlaget for denne suksessrike ferden. Skrevet av Arvid Brodersen, hadde utgaven for 80 år siden tittelen «Amerika i verdenspolitikken».

Grunnlagt av Norsk komité for internasjonale spørsmål for å gi «sakkyndig og objektiv oplysning» med sikte på å «skape en oplyst og uavhengig opinion» på et felt som «spiller en stadig større rolle i den offentlige diskusjon», var IP tenkt som grunnpilaren i arbeidet med å fremme «en ny vitenskapsgren, 'International Relations', som omfatter utenrikspolitikk og andre mellomfolkelige problemer.» I sin første årgang utkom det seks tematiske hefter (alle sitater fra programerklæringen trykket i første utgaven; se Leira og Neumann 2007 for en bredere diskusjon). Fra mars 1940 til to år etter frigjøringen fra den tyske okkupasjonen var det pause i IPs publisering.

I «Amerika i verdenspolitikken» ga Brodersen leserne innsyn i USAs særegenhet og tok frem aspekter ved samfunnsutviklingen som han mente kunne komme til å påvirke USAs stilling i verden og dets utenrikspolitikk. Interessant nok er det mye $\mathrm{i}$ IPs første hefte, trykket for 80 år siden, som fortsatt kan leses med relevans for dagens situasjon. Blant Brodersens betraktninger kan man lese at «Nasjonal solidaritetsfølelse finnes nok, men den ytrer sig til daglig ikke i forholdet til 
fremmede makter» (1937: 2). Brodersen trekker også frem faktorer som kan tenkes å endre USAs utenrikspolitikk i årene fremover, blant annet «innvandringslovene av 1924 og senere år som praktisk talt stanset den videre tilførsel av vanskelig assimilerbart menneskemateriell utenfra.» Brodersen spekulerte $i$ at mindre innvandring ville føre til et «mere utpreget lagdelt, mindre mobilt» samfunn: «Med de fremmede forsvinner det optimistiske proletariatet (optimistisk $\mathrm{i}$ håp om at iallfall neste generasjon skal kunne nå ut av proletarkår); det nye proletariatet får nødvendigvis en annen stilling og en annen ideologi. [...] Derimot er de småborgerlige mellemklasser i Amerika mere enn nogensinne en grobunn for utopiske idéer om at hver amerikaner kan leve et overdådig herreliv den dag samfundets økonomiske og tekniske muligheter virkeliggjøres til like fordel for alle» (1937: 20). Om utenrikspolitikken skrev Brodersen at «Den linje de følger er stort sett den negative isolasjonisme: 'så lite utenrikspolitikk som mulig', og fremfor alt: ingen innblanding $\mathrm{i}$ eller fra Europa, eller som en senator fra en av farmerstatene uttrykte sig en gang: 'To hell with Europe and all those nations'» (1937: 2).
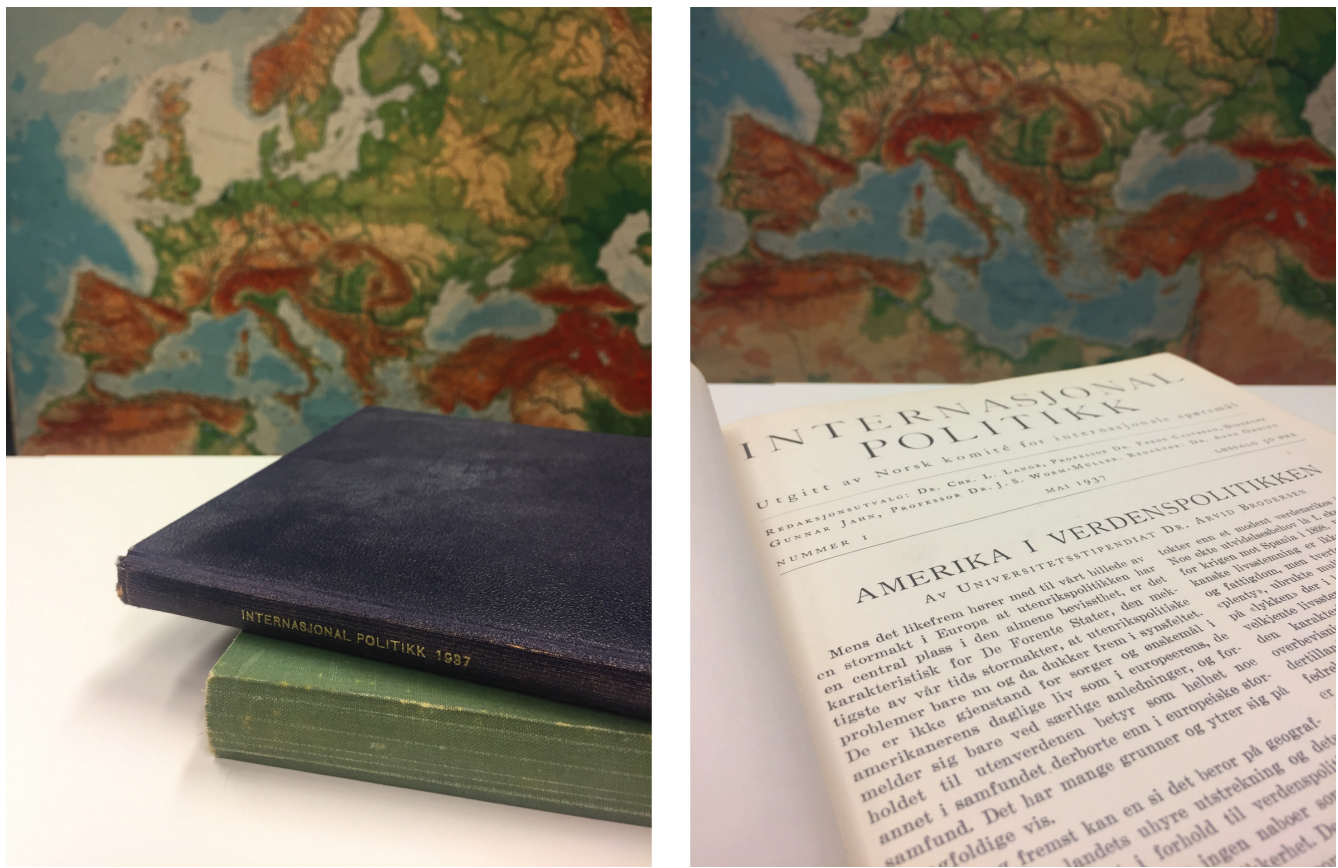

Denne lederen markerer begynnelsen av en ny fase for IP. Med ny undertittel Skandinavisk tidsskrift for Internasjonale Studier - ønsker vi å markere tidsskriftets allerede etablerte skandinaviske profil, men også styrke tidsskriftets målsetning om å befeste posisjonen som Skandinavias ledende tidsskrift for internasjonale spørsmål. Vårt håp er at tidsskriftets policy om Open Access (OA) vil gjøre det like naturlig for en forsker i Danmark eller Sverige å publisere hos oss, som det har vært for en forsker i Norge. En ny redaksjon medfører også noen endringer i redaksjonelle rutiner, og for 
å gjøre tidsskriftet til en mer dynamisk plattform for faglig meningsbrytning vil artikler publiseres kontinuerlig.

Gjennom sine 75 årganger har 80-åringen gjennomgått en rekke faser, fra grunnleggende folkeopplysning via en blanding av fagartikler og aktuelt materiale til omstillingen mot Open Access (OA) fra 2016. Som nye redaktører av IP fra 2017 ønsker vi å bygge videre på dette fundamentet først og fremst gjennom tre grep: mer tverrfaglighet, styrke aktualitetsorientering, samt bygge ut den skandinaviske plattformen.

IP speiler et dobbelt formål som også ligger til grunn for NUPI - dybde og bredde. IP kan og bør derfor ikke bli et rendyrket fagtidsskrift eller et rent aktualitetsmagasin. Det langsiktige overordnede målet for IP er derfor å opprettholde og videreutvikle den kreative spenningen som ligger $\mathrm{i}$ å kombinere det beste av faglig innsikt med målet om å opplyse og informere bredere lag av befolkningen om aktuelle saker. Den faglige kvaliteten skal likevel være et ankerfeste, og med unntak av de redaksjonelt vurderte bokomtalene, vil resten av bidragene være fagfellevurderte.

Relatert til ønsket om bredde vil vi også styrke det tverrfaglige perspektivet i IP. Tidsskriftet Internasjonal Politikk har som nevnt fra nå av undertittelen Skandinavisk tidsskrift for internasjonale studier. Mens internasjonal politikk typisk referer til fokus på mellomstatlige relasjoner, internasjonale organisasjoner og lands utenrikspolitikk (ved norske universiteter som regel underlagt statsvitenskap), er internasjonale studier ment å markere et enda bredere nedslagsfelt - ikke ulikt redaksjonens ønske fra 1937 om et fokus som 'omfatter utenrikspolitikk og andre mellomfolkelige problemer'. Det «internasjonale» skal dermed også være en mulighet for å gå på tvers av fagdisiplinære rammer som sosiologi, historie, antropologi og statsvitenskap. Redaksjonens fagbakgrunn gjenspeiler også denne tverrfagligheten, med bakgrunn fra bl.a. antropologi, historisk sosiologi, områdestudier, statsvitenskap og Internasjonale Relasjoner.

IP er i dag et veldrevet og solid tidsskrift. Likevel har tidsskriftet en noe lav synlighet $\mathrm{i}$ offentligheten og $\mathrm{i}$ fagmiljø. Dette kan ha noe å gjøre med at mye av debattene om internasjonal politikk foregår på engelsk, men Open Accessovergangen har gitt oss en gylden mulighet til å videreutvikle fagtidsskriftet til å bli mer sentralt. Vi ser frem til å gripe denne muligheten. Vi vil også benytte IPs OAside til kontinuerlig publisering av materiale. Heller enn å publisere fire ganger $\mathrm{i}$ året, vil vi ha løpende publisering av fagartikler, og fokusspalter fire ganger $\mathrm{i}$ året. Vi oppfordrer de som ikke allerede har gjort det å registrere seg for varsler om nye IP-artikler.

Gitt økende konkurranse, nasjonalt, nordisk og internasjonalt, er det ingen selvfølge at IP vil kunne beholde den statusen tidsskriftet har i dag. Tradisjonen gir oss en grunnmur å bygge videre på, men IP må videreutvikles. Overgangen mot OA blir et viktig skritt i videreutviklingen som vil bidra til å tilgjengeliggjøre tidsskriftet for flere lesere og flere forfattere i Skandinavia på skandinavisk (svensk, norsk og dansk). Vi vil jobbe for å gjøre IP til et ledende faglig forum for internasjonale 
spørsmål på skandinavisk språk og være på høyde med anerkjente internasjonale fagtidsskrifter, samtidig som aktualitetsprofilen gjøres mer eksplisitt relevant for det pågående offentlige ordskiftet om internasjonale spørsmål. IPs lesere må i større grad få innsikt i løpende internasjonale fagdebatter. Vi vil derfor aktivt oppmuntre oversiktsartikler om fagutviklingen. Tidsskriftet skal være den sentrale kanalen for disseminering av internasjonale fagdebatter i Norge.

Den første fokusspalten - om USA og Skandinavia - reflekterer flere av disse målene. Den nye redaksjonen ønsker å fortsette det arbeidet som ble startet av den forrige, og inkludere debatter rundt de skandinaviske og/eller nordiske landenes utenriks- og sikkerhetspolitikk. Temaet for spalten er de skandinaviske landenes forhold til USA i utenriks- og sikkerhetspolitikken, med bidragsytere fra Danmark, Norge og Sverige. Spalten ble igangsatt før det amerikanske presidentvalget, og de syv bidragsyterne har fått den vanskelige oppgaven med å også måtte reflektere over hva valget av Trump innebærer for det transatlantiske forholdet.

Allerede i 1937 dro Brodersen paralleller mellom de skandinaviske landene og USA: «I sin typiske holdning gjør gjennemsnittsamerikaneren til sitt eget det ord som blev sagt om vårt land: Vår utenrikspolitikk er at vi ingen utenrikspolitikk har. [...] Et lite land kan kanskje gjøre alvor av et slikt ord, skjønt neppe ute å skade sig selv, som vår historie viser. Et stort land med en tallrik befolkning kan det derimot ikke» (1937: 2).

God lesning!

Benjamin de Carvalho, Minda Holm og Niels Nagelhus Schia

Redaktører

\section{Referanser}

Brodersen, Arvid (1937) «Amerika i verdenspolitikken», Internasjonal Politikk 1(1), ss. 1-20.

Leira, Halvard og Iver Neumann (2007) «Internasjonal Politikk i Norge: En disiplins fremvekst i første halvdel av 1900-tallet», Internasjonal Politikk 65(2), ss. 141-171. 